\title{
Genotypic characterization of xanthomonad strains isolated from passion fruit plants (Passiflora spp.) and their relatedness to different Xanthomonas species
}

\author{
Edmilson R. Gonçalves and Yoko B. Rosato
} Author for correspondence: Yoko B. Rosato. Tel: +55 19 7881135. Fax: +55 197881089.
e-mail: yrosato@obelix.unicamp.br

Department of Genetics, CBMEG, State University of Campinas, 13087-930 Campinas, SP, Brazil
The genetic diversity of $\mathbf{5 5}$ xanthomonad strains isolated from passion fruit plants (Passiflora spp.) and identified as Xanthomonas campestris pv. passiflorae was initially assessed by randomly amplified polymorphic DNA (RAPD) analysis. The strains showed a high level of polymorphism with almost unique fingerprints. Fifteen clusters with a similarity of $\sim 70 \%$ were identified, three of which were prevalent. There was a correlation between the clusters and the geographic origin of the strains. A representative strain of each cluster, together with the pathovar reference strain, were used to verify the relationships of these strains to 18 Xanthomonas species and Pseudomonas syringae pv. passiflorae. All Xanthomonas species yielded a unique RAPD profile and no consistent relatedness to the $X$. campestris $p v$. passiflorae strains was observed. Amplification products were also analysed by repetitive (rep) primers (BOX, ERIC and REP), RFLP of the 16S-23S rDNA intergenic spacer and SDS-PAGE of whole-cell proteins. All of these approaches generated profiles characteristic for each Xanthomonas species but the taxonomic position of the $X$. campestris pv. passiflorae strains could not be unequivocally assigned. Finally, DNA-DNA hybridization allowed a sound taxonomic allocation of the strains to Xanthomonas axonopodis pv. passiflorae.

Keywords: Xanthomonas, RAPD, rep-PCR, RFLP-16S-23S, SDS-PAGE of wholecell proteins

\section{INTRODUCTION}

Xanthomonas campestris is a species complex including mainly phytopathogens which cause diseases in various economically important plants. The species includes pathovars designated according to their hosts. X. campestris pv. passiflorae (Pereira, 1969) Dye 1978, a pathogenic bacterium of passion fruit (Passiflora spp.), is a pathovar rarely included in general or taxonomic studies, perhaps because the host plant is cultivated in tropical and subtropical regions. In recent years passion fruit has become a commercial product in the Brazilian juice industry and large-scale cultivation now occurs. Only two varieties of passion fruit

Abbreviations: IGS, intergenic spacer; RAPD, randomly amplified polymorphic DNA. are exploited commercially (Passiflora edulis Sims and Passiflora edulis f. flavicarpa), although about 400 species have been described (Souza \& Meletti, 1997). An area of 25000 ha is currently used to produce passion fruit in Brazil (Teixeira, 1994) and the commercial demand has been increasing gradually. Concomitant with the expansion of passion fruit production, the incidence of disease is also rising (Torres Filho \& Ponte, 1994). Bacteriosis, caused by $X$. campestris pv. passiflorae, is a major disease limitation in the development of cultivated areas in Brazil. The disease, designated premature death, has been increasing since the late 1970s (Torres Filho \& Ponte, 1994). Infection occurs through natural openings and lesions and results in systemic invasion of the whole plant. In the leaves, the disease causes necrosis and soaked, greasy lesions of irregular shape surrounded by chlorotic areas. The fruit is also affected, with the 
Table 1. X. campestris pv. passiflorae strains used

\begin{tabular}{|c|c|c|c|}
\hline Strains & Host & Sampling site & State* \\
\hline $\begin{array}{l}8930,11061,11323,11324,11325 \\
11327,11329,11330,11331\end{array}$ & Passiflora edulis & Londrina & PR \\
\hline 11341,11342 & Passiflora edulis & S. Sebastião da Amoreira & PR \\
\hline 11043 & Passiflora edulis & Siqueira Campos & PR \\
\hline 11343 & Passiflora edulis & Arapoti & PR \\
\hline 11405 & Passiflora edulis & Marumbi & PR \\
\hline 11406 & Passiflora edulis & Apucarana & PR \\
\hline 11407 & Passiflora edulis & Nova Esperança & PR \\
\hline $120,428,444,445$ & Passiflora edulis & Campinas & SP \\
\hline 121,148 & Passiflora edulis & Valinhos & SP \\
\hline 617 & Passiflora edulis & Registro & SP \\
\hline 658 & Passiflora alata & Guaiçara & SP \\
\hline 777 & Passiflora edulis & Bragança Paulista & SP \\
\hline $941,960,1007$ & Passiflora edulis & Vera Cruz & SP \\
\hline 996,997 & Passiflora edulis & Tupã & SP \\
\hline 1039 & Passiflora edulis & Pilar do Sul & SP \\
\hline 1040 & Passiflora edulis & Paulínia & SP \\
\hline 1151 & Passiflora edulis & S. João da Boa Vista & SP \\
\hline 1154 & Passiflora edulis & Jaguariúna & SP \\
\hline 1166 & Passiflora edulis & Dracena & SP \\
\hline 1168 & Passiflora edulis & Cosmópolis & SP \\
\hline 1171 & Passiflora alata & Indaiatuba & SP \\
\hline 674 & Passiflora sp. & Araguari & MG \\
\hline $\begin{array}{l}649,714,715,712,717,767, \\
1053,621\end{array}$ & Passiflora sp. & Brasília & $\mathrm{DF}$ \\
\hline $686,687,688$ & Passiflora sp. & Feira de Santana & BA \\
\hline 720,748 & Passiflora sp. & Propriá & SE \\
\hline $591,592,593$ & Passiflora sp. & Ibiapaba & $\mathrm{CE}$ \\
\hline ICMP $3151 \uparrow$ & Passiflora sp. & Araraquara & SP \\
\hline
\end{tabular}

* State in Brazil; see legend to Fig. 1.

$\dagger$ Pathovar reference strain from the International Collection of Microorganisms from Plants, Auckland, New Zealand.

appearance of hard greasy spots making it unsuitable for consumption and industrial processing.

Reclassification of the genus Xanthomonas has been proposed by Vauterin et al. (1995) based mainly on DNA-DNA hybridization analysis, although the phytopathological identification was retained. Accordingly, the species $X$. campestris was divided into 16 new species and the Sub-Committee on Taxonomy of Plant-pathogenic Bacteria has validated this proposal (see Young et al., 1996). However, xanthomonads from passion fruit plants have not been analysed and the former designation, $X$. campestris pv. passiflorae, has been maintained.

Genotypic diversity is being analysed increasingly by PCR-based methods. By using short arbitrary primers [randomly amplified polymorphic DNA (RAPD)PCR] or primers binding to repetitive extragenic sequences, BOX, ERIC and REP, generally known as rep, high-resolution genomic fingerprinting can be obtained (Welsh \& McClelland, 1990; Versalovic et al., 1991). The rep primers correspond to conserved motifs in bacterial repetitive elements which have also been found in Xanthomonas and other phytopathogenic bacteria (Louws et al., 1994, 1995). Both approaches are intensively used to assess genetic diversity and as an additional tool for bacterial classification (de Bruijn, 1992). Other molecular methods, including SDS-PAGE and multilocus enzyme electrophoresis are frequently employed in studies of Xanthomonas (Vauterin et al., 1991). A more conserved genetic characteristic, the 16S-23S intergenic spacer (IGS) of the rDNA operon, has also been used to infer the phylogenetic relationships and identification of bacteria at different taxonomic levels (see Gürtler \& Stanisich, 1996).

In this study we examined the genetic diversity of 55 strains of $X$. campestris pv. passiflorae (referred to as passiflorae strains) isolated from infected passion fruit leaves collected from different geographic regions of Brazil. The relatedness of a representative strain of 15 clusters generated by RAPD, 16 species of Xanthomonas and Pseudomonas syringae pv. passiflorae was 
verified by comparison of the genomic fingerprints generated by RAPD, rep-PCR, RFLP-IGS and SDSPAGE of whole-cell proteins. A sound taxonomic allocation of the passiflorae strains within the genus Xanthomonas was obtained by DNA-DNA hybridization.

\section{METHODS}

Bacterial strains and culture medium. All X. campestris pv. passiflorae strains (Table 1) were obtained from the collection of the Instituto Biológico, Section of Phytopathological Bacteriology (IBSBF), Campinas, SP, Brazil, and from the Instituto Agronômico do Paraná (IAPAR), Londrina, PR, Brazil. The strains were collected from different states in Brazil (Fig. 1). Two strains, 960 and 1171, showed white colonies and were confirmed as pathogens of Passiflora alata. For comparison, other type and reference strains from the species of Xanthomonas described by Vauterin et al. (1995) were also used. The following type and reference strains were purchased from the culture collection of the Laboratorium voor Microbiologie, Universiteit Gent, Belgium: Xanthomonas axonopodis pv. axonopodis LMG $538^{\mathrm{T}}$, Xanthomonas bromi LMG $947^{\mathrm{T}}, X$. campestris pv. campestris LMG 568 ${ }^{\mathrm{T}}$, Xanthomonas cassavae LMG $673^{\mathrm{T}}$, Xanthomonas codiaei LMG 8678 ${ }^{\mathrm{T}}$, Xanthomonas cucurbitae
LMG $690^{\mathrm{T}}$, Xanthomonas hortorum pv. hederae LMG 733, Xanthomonas hyacinthi LMG $739^{\mathrm{T}}$, Xanthomonas melonis LMG $8670^{\mathrm{T}}$, Xanthomonas pisi LMG $847^{\mathrm{T}}$, Xanthomonas oryzae pv. oryzae, LMG 5047, Xanthomonas sacchari LMG $471^{\mathrm{T}}$, Xanthomonas theicola LMG $8684^{\mathrm{T}}$, Xanthomonas translucens pv. translucens LMG $876^{\mathrm{T}}$, Xanthomonas vasicola pv. holcicola LMG $736^{\mathrm{T}}$, Xanthomonas vesicatoria LMG $911^{\mathrm{T}}$ and $P$. syringae pv. passiflorae LMG 5185. The strains Xanthomonas albilineans ICMP 196, Xanthomonas arboricola pv. juglandis ICMP 35 and $X$. campestris pv. passiflorae ICMP 3151 were provided by the International Collection of Microorganisms from Plants (ICMP), Auckland, New Zealand. All strains were grown on NYG medium (Turner et al., 1984) at $30^{\circ} \mathrm{C}$.

DNA extraction. An aliquot $(1.5 \mathrm{ml})$ of bacterial suspension, grown overnight, was washed with $500 \mu \mathrm{l}$ TAS buffer (50 mM Tris/ $\mathrm{HCl} \mathrm{pH} 7 \cdot 8,50 \mathrm{mM}$ EDTA, $150 \mathrm{mM} \mathrm{NaCl}$ ), centrifuged and resuspended in $450 \mu \mathrm{l}$ of the same buffer. Fifty microlitres of SDS $(10 \%, \mathrm{w} / \mathrm{v})$ and $100 \mu \mathrm{g}$ proteinase $\mathrm{K}$ were added and the mixture was incubated for $1 \mathrm{~h}$ at $55^{\circ} \mathrm{C}$. Proteins and cell debris were extracted with phenol and chloroform and the aqueous suspension was then

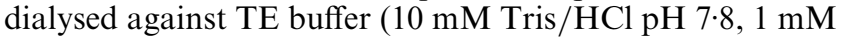
EDTA) for $48 \mathrm{~h}$. DNA concentration was estimated by comparison with known concentrations of $\lambda$ DNA in agarose gel electrophoresis (Sambrook et al., 1989).

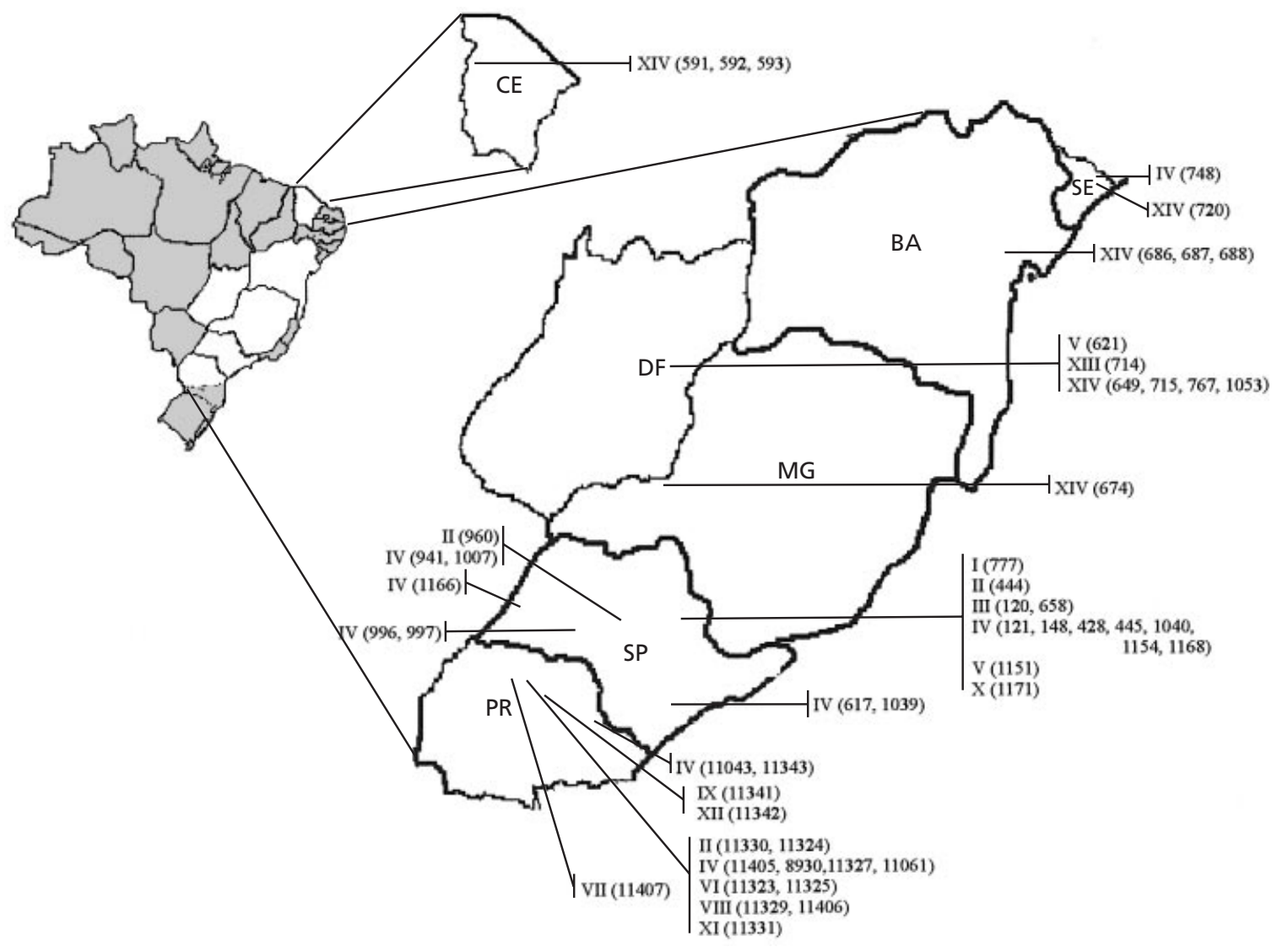

Fig. 1. Collection sites of $X$. campestris pv. passiflorae strains in Brazil. The Roman numerals refer to the clustering group obtained by RAPD analysis. The state name abreviations are: BA, Bahia; CE, Ceará; DF, Federal District; MG, Minas Gerais; PR, Paraná; SE, Sergipe; and SP, São Paulo. 
PCR amplification. All PCR reactions were performed in a total volume of $25 \mu \mathrm{l}$ using $20-50 \mathrm{ng}$ DNA. In the RAPD amplification, the primers OPR2, OPR6, OPR8 and OPQ4 (Operon Technologies) were used. The reaction contained $3.75 \mathrm{mM} \mathrm{MgCl}_{2}, 100 \mu \mathrm{M} \mathrm{dNTP}, 5 \mu \mathrm{M}$ primer and $0.5 \mathrm{U}$ Taq polymerase $(\mathrm{BRL})$. The following cycling conditions were used: $1 \times 94{ }^{\circ} \mathrm{C}$ for $3 \mathrm{~min} ; 45 \times\left(94{ }^{\circ} \mathrm{C}\right.$ for $1 \mathrm{~min}, 34{ }^{\circ} \mathrm{C}$ for $1 \mathrm{~min}, 72^{\circ} \mathrm{C}$ for $2 \mathrm{~min}$ ). The rep primers (BOX, ERIC, REP) were used as described by Louws et al. (1994) with $100 \mu \mathrm{M}$ dNTP for BOX and $300 \mu \mathrm{M}$ for ERIC and REP. Amplification of the 16S-23S rDNA IGS was performed using the primers $16 \mathrm{~S}$ uni330 and 23S uni322anti (Honeycutt et al., 1995). The PCR reaction contained $3.75 \mathrm{mM} \mathrm{MgCl}_{2}$, $100 \mu \mathrm{M}$ dNTP, $5 \mu \mathrm{M}$ primer and $0.5 \mathrm{U}$ Taq polymerase (Pharmacia). The cycling conditions were: $1 \times 94^{\circ} \mathrm{C}$ for $1 \mathrm{~min} ; 40 \times\left(94^{\circ} \mathrm{C}\right.$ for $30 \mathrm{~s}, 65^{\circ} \mathrm{C}$ for $30 \mathrm{~s}, 72^{\circ} \mathrm{C}$ for $\left.1 \mathrm{~min}\right)$. Control reactions without DNA template were also run. The PCR amplifications were repeated at least twice for most of the strains. The DNA banding patterns obtained following electrophoresis in $1.2 \%$ agarose gels were recorded in a binary form (presence/absence). RFLP-IGS patterns were obtained by digestion of the amplification product $(3-5 \mu \mathrm{l})$ with the restriction enzymes DdeI, HhaI, HinfI, Pst I and Sau3AI. The digested fragments were separeted in polyacrylamide gels $(10 \%, \mathrm{w} / \mathrm{v})$ and silver-stained (De Moreno et al., 1985). The 16S rDNA gene, used as a probe to determine DNA concentration in DNA-DNA hybridization experiments, was obtained by PCR amplification of DNA from the strain ICMP 3151. The primers 16F27 and 16R1525 (Hauben et al., 1997) were used in a reaction containing 20-50 ng DNA, $1.5 \mathrm{mM} \mathrm{MgCl}, 100 \mu \mathrm{M}$ dNTP, $0.5 \mu \mathrm{M}$ of the primers and $0.5 \mathrm{U}$ Taq polymerase (Pharmacia), in a total volume of $25 \mu \mathrm{l}$. The sample was cycled under the following conditions: $1 \times 94{ }^{\circ} \mathrm{C}$ for $2 \mathrm{~min}$; $40 \times\left(94{ }^{\circ} \mathrm{C}\right.$ for $1 \mathrm{~min}, 55^{\circ} \mathrm{C}$ for $1 \mathrm{~min}, 72^{\circ} \mathrm{C}$ for $1 \mathrm{~min}$ ). The PCR product was purified from low-melting-point agarose gel according to Sambrook et al. (1989). In all cases, control reactions lacking DNA template were run.

SDS-PAGE of whole-cell proteins. SDS-PAGE was performed according to Jackman (1985) and Vauterin et al. (1991). Freshly grown cells (about $30 \mathrm{mg}$ ) were resuspended in TE buffer (10 mM Tris/HCl pH 8, 1 mM EDTA), washed and resuspended in $100 \mu \mathrm{l}$ of the sample buffer $(62.5 \mathrm{mM}$ Tris $/ \mathrm{HCl} \mathrm{pH} \mathrm{8.0,} \mathrm{20 \%} \mathrm{(v/v)} \mathrm{glycerol,} \mathrm{2 \%} \mathrm{SDS,} \mathrm{5 \%} \beta$ mercaptoethanol, $0.02 \%$ bromophenol blue). The mixture was heated at $95^{\circ} \mathrm{C}$ for $5 \mathrm{~min}$, centrifuged for $10 \mathrm{~min}$ and approximately $7 \mu \mathrm{l}$ of the supernatant was loaded onto the gel. Electrophoresis was performed in a polyacrylamide gel (10 and $4 \%$ total acrylamide for the running and stacking gels, respectively). After electrophoresis, the protein bands were visualized by silver-staining (Blum et al., 1987).

Data analysis. Data from the RAPD, rep-PCR and RFLPIGS were scored in binary form (presence/absence) and similarity matrices were generated using the Jaccard coefficient $\left(S_{\mathrm{J}}\right)$. Relationships among strains were calculated with the algorithm UPGMA (unweighted pair group method with arithmetic averages) using the software package NTSYSPC (Applied Biostatistics, Inc.).

DNA-DNA hybridization. Hybridization was performed using nylon membranes (Amersham) and a Hybri slot-blot manifold as described by the manufacturer (Bio-Rad). The probes were labelled using a DIG DNA labelling kit, and the bands were detected with the chemiluminescent substrate CSPD (disodium 3-(4-methoxyspiro\{1,2-dioxetane-3,2'-(5'chloro) tricyclo [3.3.1.1 $1^{3,7}$ decan $\left.\}-4-y l\right)$ phenyl phosphate) as recommended by the manufacturer (Boehringer Mannheim). The signal, detected by exposure to X-ray film (Kodak), was measured using an Ultrascan XL-enhancer laser densitometer (LKB Bromma).

\section{RESULTS}

\section{Extensive polymorphism within the passiflorae group revealed by RAPD analysis}

All passiflorae strains were collected from 1968 to 1996 in different states of Brazil (Fig. 1), mainly São Paulo and Paraná, and deposited in the IBSBF and IAPAR collections. The regions shown in Fig. 1 were broadly divided into a Northern region, consisting of the states of Bahia (BA), Ceará (CE), Distrito Federal (DF), Minas Gerais (MG) and Sergipe (SE); and a Southern region consisting of the states of Paraná (PR) and São Paulo (SP).

Preliminary RAPD experiments were conducted with 10 strains, using 13 primers to standardize the PCR conditions and to choose the appropriate primers. Most of the primers yielded no amplification or produced inconsistent PCR products and were not used. Four primers (OPR2, OPR6, OPR8 and OPQ4) were selected to assess the diversity among the $55 X$. campestris pv. passiflorae strains. In the first evaluation, all $X$. campestris pv. passiflorae strains and the pathovar reference strain (ICMP 3151) were analysed. The PCR reaction was run at least twice for each strain. Inconsistent bands were checked by performing a third run. The primer OPR2 yielded fragments ranging from 0.3 to $1.6 \mathrm{~kb}$ and nine fragments were considered for analysis. A $1.0 \mathrm{~kb}$ band was common to all strains and variation was detected with the smaller fragments. Six different patterns were obtained and two major ones were shown by more than $75 \%$ of the strains. OPR6 amplified up to four fragments per strain $(0.3-2.5 \mathrm{~kb})$ and eight bands were included in the cluster analyses. A $2.5 \mathrm{~kb}$ band was shown by all strains. Two patterns were prevalent among the six detected. OPR 8 produced greater polymorphism but visualization of the fragments was more difficult. Two bands, of 0.3 and $1.0 \mathrm{~kb}$, were shared by all strains and the bands between these sizes yielded most of the differences among the strains. OPQ4 showed the lowest level of polymorphism, amplifying fragments of 0.5 $2.0 \mathrm{~kb}$. Two bands $(0.8$ and $1.4 \mathrm{~kb})$ were shared by all strains. Five different patterns were detected, one of which was shown by more than $90 \%$ of the strains.

In the dendrogram constructed using 34 scored bands from the RAPD data (Fig. 2), few strains showed an identical RAPD pattern and three major clusters included $94 \%$ of the strains. One cluster comprised seven strains, isolated from different hosts (P. edulis, $P$. alata or Passiflora spp.) from the Southern states. A second cluster included 27 strains collected in the same region (Southern) but showed no correlation to the host and only two strains (748 and 621) were from the Northern region. A third cluster included 15 strains 


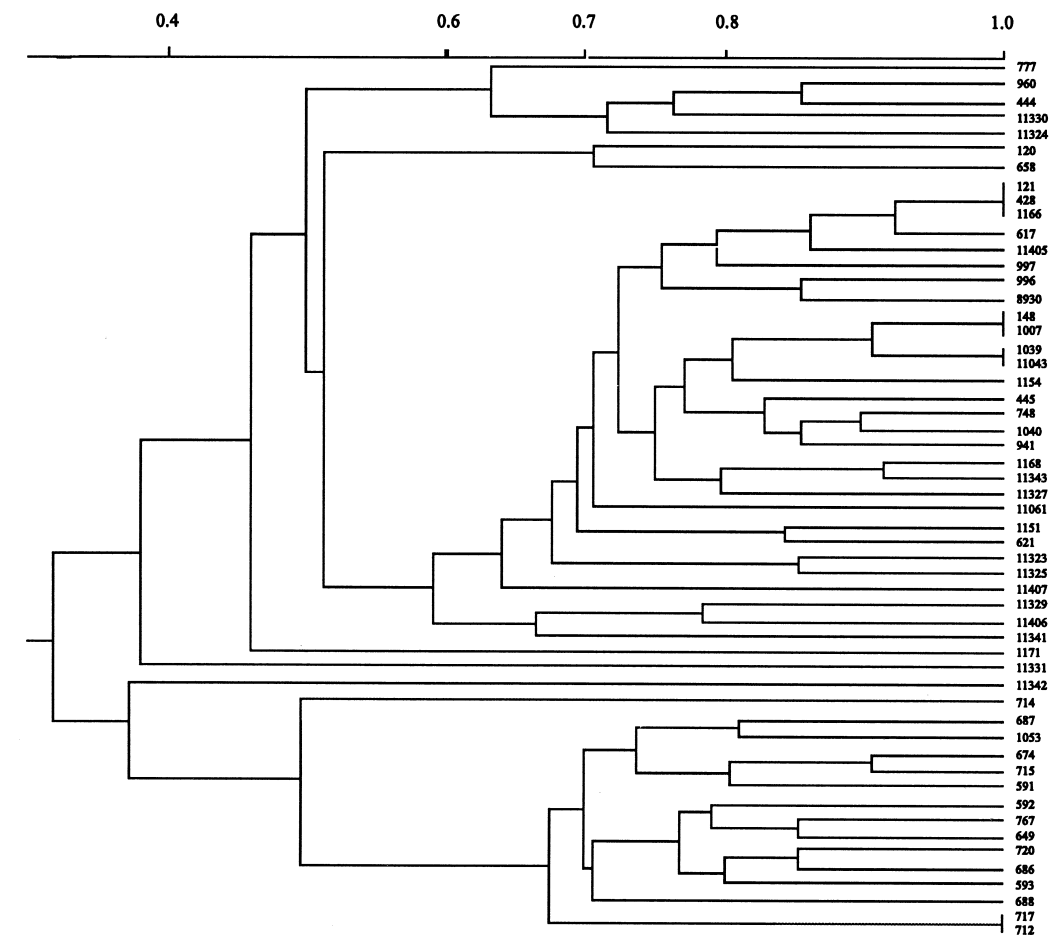

Fig. 2. Clustering ( $S /$ /UPGMA) obtained from $54 X$. campestris pv. passiflorae strains based on RAPD data for the primers OPR2, OPR6, OPR8 and OPQ4. Scale bar indicates similarity. from the Northern states; most of these strains were isolated from an unknown host (Passiflora sp.). Five strains $(714,1171,11407,11331$ and 11342) were not grouped and remained separated from the others.

A limit of $70 \%$ of similarity was chosen in order to select representative strains of each cluster for further analysis. Accordingly, the 15 strains (I-XV) representing each cluster were: $777,11324,120,121,1151$, 11323, 11407, 11329, 11341, 1171, 11331, 11342, 714, 592 and 717. Fig. 1 shows the distribution of all passiflorae strains designated by their cluster number. Clusters I-XII were collected in the Southern states, with a prevalence of strains from cluster IV (20 strains), which was widely distributed in both states (SP and PR). In contrast, strains from clusters XIII-XIV were found exclusively in the Northern region, with a prevalence of strains from cluster XIV (12 strains). These results indicate that the two regions have distinct populations (clusters) with almost no overlapping. Only two strains (748 and 621), from clusters IV and V, respectively, were found in the Northern states.

\section{Relatedness of the selected passiflorae strains to different Xanthomonas species as assessed by RAPD}

In a second evaluation by RAPD, the profiles of the 15 selected passiflorae strains and the pathovar reference strain, ICMP 3151, were compared to those obtained with 16 species of Xanthomonas and P. syringae pv. passiflorae using the primers OPR2, OPR6, OPR 8 and OPQ4. A high level of polymorphism was detected and each species of Xanthomonas yielded a unique genomic fingerprint. With OPR2, bands ranging from $0 \cdot 3$ to $3.0 \mathrm{~kb}$ were obtained and 23 bands were scored. All species showed a distinct profile; in some cases the profiles were similar but differed in at least one major band. OPR6 amplified fragments ranging from 0.5 to $3.0 \mathrm{~kb}$ and 20 bands were used in the analysis. This primer did not amplify DNA from $X$. pisi and $X$. oryzae. OPR 8 produced fragments between $0 \cdot 3$ and $2 \cdot 3 \mathrm{~kb}$ and 15 bands were scored. With OPQ4, 15 bands varying from 0.4 to $2 \cdot 8 \mathrm{~kb}$ were used in the analysis. A total of 73 bands obtained with the four primers were used to construct the dendrogram based on a UPGMA algorithm (Fig. 3a). Each representative strain of the different Xanthomonas species showed a very distinctive pattern and the level of similarity among them was lower than $45 \%$. Some species, such as $X$. campestris and $X$. axonopodis, were closely related to each other ( $45 \%$ similarity) and the passiflorae strains were also closer to these two species and to $X$. vasicola and $X$. oryzae ( $17 \%$ similarity) than to the other species $(<10 \%$ similarity).

\section{rep-PCR fingerprintings of selected passiflorae strains and Xanthomonas species}

The set of rep primers, BOX, ERIC and REP, was used to amplify DNA from 16 passiflorae strains, 18 Xanthomonas species and P. syringae pv. passiflorae. Analysis of the individual and combined patterns using the three sets of primers revealed considerable genetic diversity. Amplification with $\mathrm{BOX}$ primers yielded 27 scorable bands, ranging from 4.0 to $0.5 \mathrm{~kb}$. Within the passiflorae group, some strains showed 
(a)

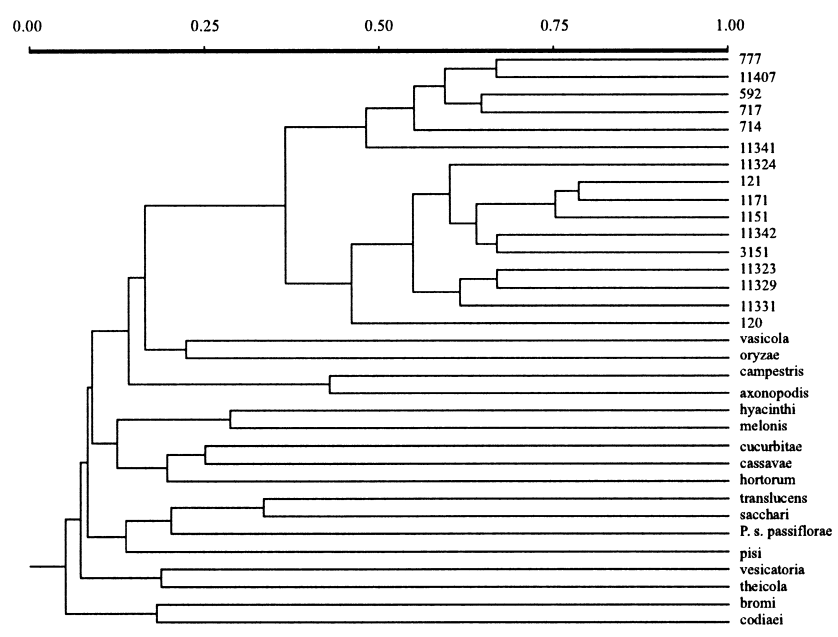

(b)

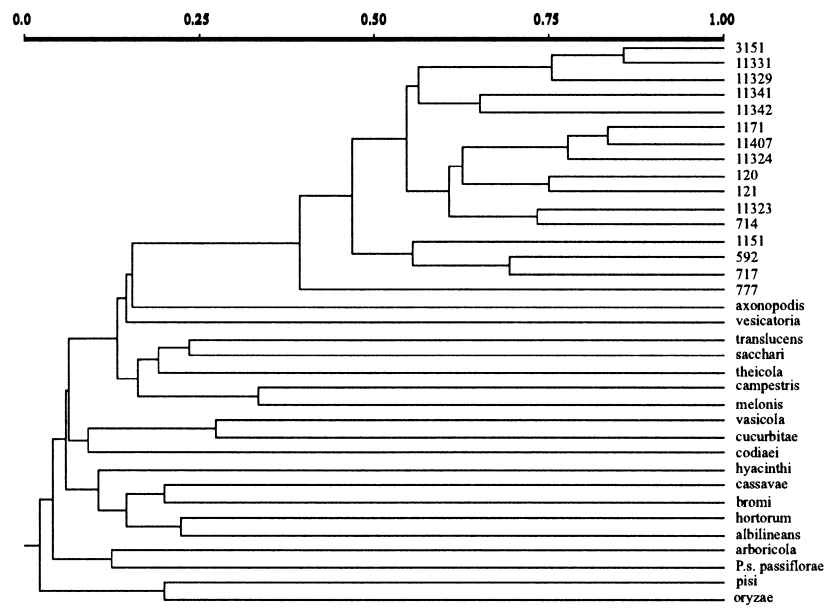

Fig. 3. (a) Clustering ( $S_{J} /$ UPGMA) of 16 selected passiflorae strains and 16 Xanthomonas species based on RAPD data for the primers OPR2, OPR6, OPR8 and OPQ4. (b) Clustering (S,/UPGMA) obtained for the selected passiflorae strains and other Xanthomonas species using the combined data from repPCR experiments. Scale bar indicates similarity.

identical patterns $(3151=120=121,1151=11329$, $1171=11407)$ and even though a reasonable degree of diversity was detected, a unique cluster was formed. Two bands $(\sim 0.7$ and $\sim 0.6 \mathrm{~kb})$ were consistently shared by all passiflorae strains. ERIC primers yielded a broader range of variation and other Xanthomonas species (cassavae, campestris and melonis) were embedded within the passiflorae group. A total of 20 bands, most of them varying from 0.5 to $3.0 \mathrm{~kb}$, were considered for cluster analysis. A very intense and high-molecular-mass $(5 \cdot 0 \mathrm{~kb})$ band was observed with $X$. arboricola. Amplification with REP primers showed unique patterns for the Xanthomonas species. A total of 16 bands $(0 \cdot 3-3 \cdot 1 \mathrm{~kb})$ were scored and included in the analysis. Two strains (11329 and 11341) showed

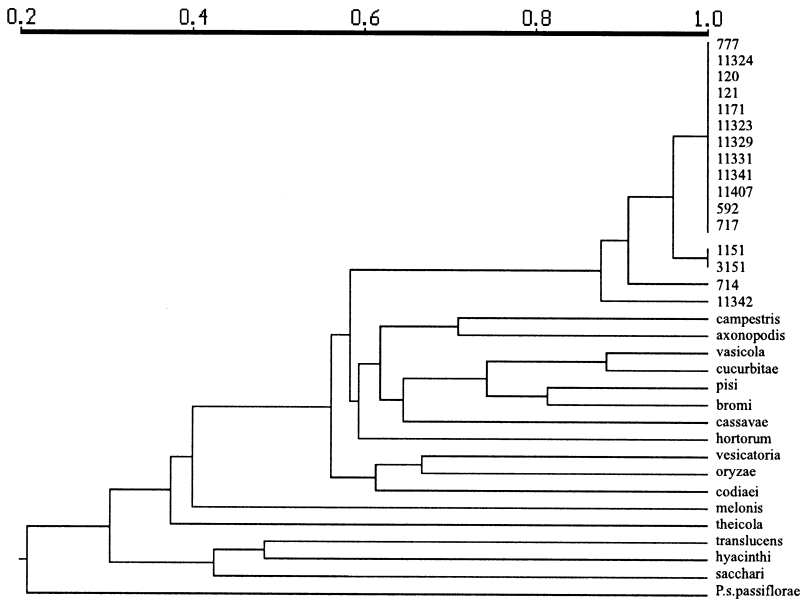

Fig. 4. Dendrogram ( $S$ /UPGMA) of the RFLP patterns of the 16S-23S rDNA IGS of passiflorae strains and other Xanthomonas species digested with the restriction enzymes Ddel, Hhal, Hinfl, Pstl and Sau3AI. Scale bar indicates similarity.

identical patterns. The Xanthomonas species were clearly differentiated from the passiflorae strains.

A dendrogram based on the combined data of the rep primers (Fig. 3b) showed that each passiflorae strain and each Xanthomonas species was identifiable by unique patterns. The genetic diversity within the passiflorae group was substantial, with similarities of $38-85 \%$. This group was distantly related to the other Xanthomonas species ( $<15 \%$ similarity). The level of relatedness among the Xanthomonas species was also very low $(<15 \%)$.

\section{RFLP-IGS of selected passiflorae strains and Xanthomonas species}

All 16 passiflorae strains and most of the Xanthomonas species yielded a single PCR product of $\sim 1 \cdot 1 \mathrm{~kb}$. The Pseudomonas species showed a higher band $(\sim 1.2 \mathrm{~kb})$. The IGS products were digested with DdeI, HhaI, HinfI, PstI and Sau3AI restriction enzymes and the products were separated in polyacrylamide gels (data not shown). A low level of polymorphism was detected within the passiflorae group and identical profiles were obtained using DdeI or HinfI. With HhaI, Pst I and Sau3AI, two patterns were obtained with each enzyme: a major pattern shown by most of the strains and a second which was shown by one or two strains. The dendrogram depicted in Fig. 4 was constructed by using 81 different bands, ranging from 20 to $\sim 1100 \mathrm{bp}$. The passiflorae strains revealed an unexpected variation of up to $15 \%$. This variation represents differences in one to three bands. Fig. 4 also shows the relationships with the other Xanthomonas species. A high degree of polymorphism was detected and the level of similarity ranged from 30 to $87 \%$. The species $X$. vasicola and $X$. cucurbitae and $X$. pisi and $X$. bromi 
(a)

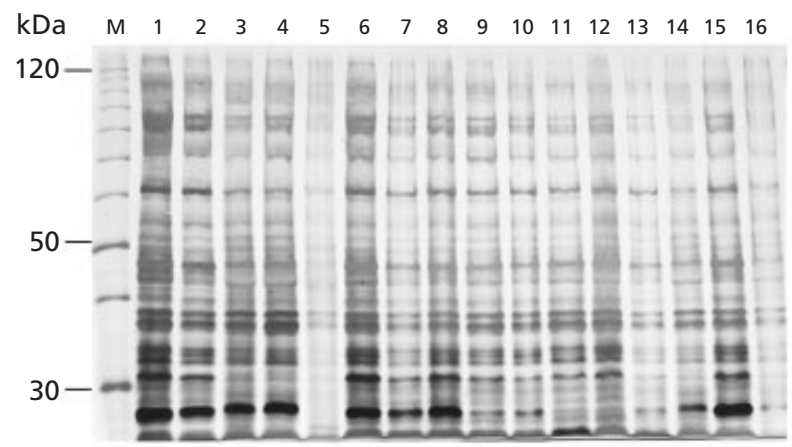

(b)

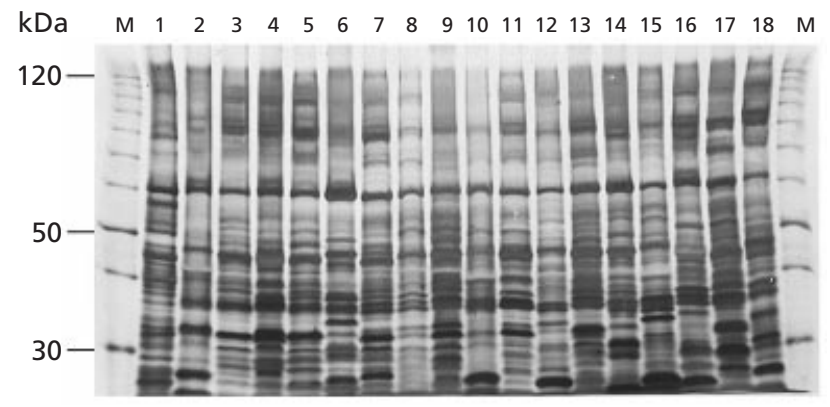

Fig. 5. SDS-PAGE of whole-cell proteins of (a) passiflorae strains and (b) other Xanthomonas species plus $P$. syringae pv. passiflorae. (a) Lanes: M, $1.0 \mathrm{~kb}$ molecular mass markers (Gibco$\mathrm{BRL}) ; 1$, ICMP 3151 (reference strain); 2, 777; 3, 120; 4, 121; 5, $714 ; 6,1171 ; 7,11324 ; 8,11323 ; 9,11407 ; 10,11329 ; 11$, $11341 ; 12,11331 ; 13,11342 ; 14,592 ; 15,1151 ; 16,717$. (b) Lanes: $M, 1.0 \mathrm{~kb}$ molecular mass markers (Gibco-BRL); 1 , ICMP 3151 (X. campestris pv. passiflorae reference strain); $2, X$. campestris; $3, X$. axonopodis; $4, X$. translucens; $5, X$. hyacinthi; $6, X$. vesicatoria; $7, X$. sacchari; $8, X$. vasicola; $9, X$. cucurbitae; $10, X$. melonis; $11, X$. cassavae; $12, X$. hortorum; $13, X$. theicola; 14, X. pisi; 15, X. bromi; $16, X$. codiaei; $17, X$. oryzae; $18, P$. syringae pv. passiflorae.

were closer to each other, whereas $X$. theicola, $X$. translucens, $X$. hyacinthi and $X$. sacchari were more distantly related to other Xanthomonas species. The passiflorae group showed $\sim 60 \%$ similarity to a major cluster which included the following species: $X$. axonopodis, X. campestris, X. vasicola, X. cucurbitae, $X$. pisi, X. bromi, X. cassavae and X. hortorum.

\section{SDS-PAGE of whole-cell proteins}

The whole-cell protein patterns of the 16 passiflorae strains, 16 species of Xanthomonas and P. syringae pv. passiflorae were analysed by SDS-PAGE (Fig. 5). The protein bands showed a very homogeneous profile within the passiflorae strains and most of the bands were shared by all strains. Differences among the strains were most commonly related to the intensity of certain bands (Fig. 5a). In contrast, the protein patterns of the Xanthomonas species showed a high level of diversity and there was no identical profile
(Fig. 5b). A band of approximately $60 \mathrm{kDa}$ was common to all Xanthomonas strains and a few other bands were considered common to some species. For example, a $52 \mathrm{kDa}$ band was exhibited by the passiflorae strains, $X$. campestris, $X$. axonopodis, $X$. vasicola, $X$. cassavae, $X$. theicola, $X$. pisi, $X$. bromi and $X$. codiaei. A dendrogram constructed (not shown) showed that the similarity within the passiflorae group was very high, ranging from 94 to $100 \%$, and a major cluster included $87.5 \%$ of the strains analysed. The passiflorae strains were more related to $X$. axonopodis, $X$. pisi, X. bromi and $X$. hyacinthi. The different Xanthomonas species had a high level of heterogeneity (25-75\%). X. axonopodis, X. pisi, X. bromi, X. hyacinthi, $X$. hortorum, $X$. codiaei, $X$. vesicatoria, $X$. vasicola, X. campestris, X. melonis and X. cassavae showed the highest similarity values, from 50 to $75 \%$. The other Xanthomonas species showed lower values $(<37 \%)$.

\section{DNA-DNA hybridization}

The hybridization was performed using DNA from the 16 passiflorae strains, 16 species of Xanthomonas and P. syringae pv. passiflorae. Digoxigenin-labelled DNA of the pathovar reference strain (ICMP 3151) was used as a probe and detected by chemiluminescence. Although similar methods have been described previously, most of them have used biotinylated DNA (see Jahnke, 1994). For this reason, the detection limit of the assay and the effect of the amount of DNA were determined. The detection level was tested using different concentrations of DNA $(100,250,500,750,1000$ and $2000 \mathrm{ng})$ from two distantly related species, $X$. campestris pv. passiflorae ICMP 3151 and $X$. albilineans. The intensity of the bands was more variable when homologous DNA was used and less than $100 \mathrm{ng}$ of DNA could be detected. However with this amount of DNA no band was seen with non-homologous DNA. For this reason, the amount of DNA used was fixed at $200 \mathrm{ng}$, which yielded a weak detectable band in non-homologous hybridization. As the amount of DNA had to be measured precisely, different methods were tested. Initially the DNA levels were estimated either by the absorbance at $260 \mathrm{~nm}$ or by visual inspection of gels containing a known amount of $\lambda$ DNA. Since neither of these methods was precise, a finer estimate was obtained by hybridization. A presumed amount of $200 \mathrm{ng}$ DNA was applied onto nylon membranes and hybridization was carried out with digoxigeninlabelled $16 \mathrm{~S}$ rDNA, obtained by PCR amplification of $X$. campestris pv. passiflorae ICMP 3151, as a probe. The homology of the 16S rDNA was assumed to be equivalent in all Xanthomonas species because of the high level of similarity of this gene (mean of $98 \%$ ) within the genus (Hauben et al., 1997). Two nylon membranes (two replicates) were prepared using the estimated 200 ng DNA from all 16 passiflorae strains, 17 Xanthomonas species and $P$. syringae pv. passiflorae and the membranes were then hybridized to the $16 \mathrm{~S}$ 
(a)

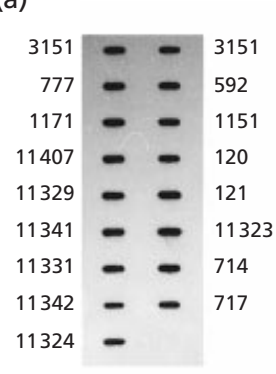

(b)

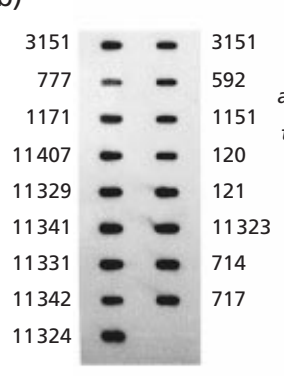

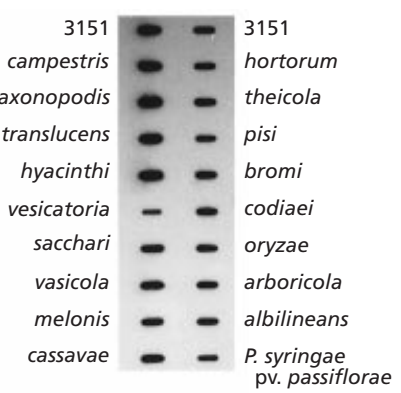

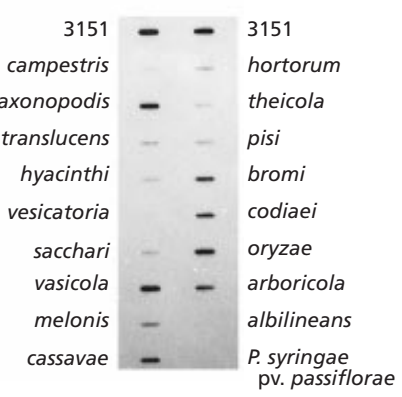

Fig. 6. DNA-DNA hybridization of passiflorae strains (left) and Xanthomonas species plus $P$. syringae pv. passiflorae (right) with a 16S rDNA probe (a) and with DNA from passiflorae ICMP 3151 as a probe (b).

rDNA probe to estimate the DNA concentration of each strain. The bands obtained (Fig. 6a) were read in a densitometer and one band was considered as a control with a defined DNA concentration. Thus, for example, a densitometer reading of $9 \cdot 7$ for the corresponding band of passiflorae ICMP 3151 was assumed as containing $200 \mathrm{ng}$ DNA. All other readings were normalized to this control. The two membranes were dehybridized and reused for hybridization with the DNA from passiflorae ICMP 3151 used as a probe. The results (Fig. 6b) were read in a densitometer, corrected for the concentration of DNA and are shown in Fig. 7. For hybridizations within the passiflorae group, all strains showed homologies of $73-160 \%$. Hybridization of the passiflorae ICMP 3151 to other Xanthomonas species revealed two groups of DNA homology. One group, with DNA homology values between 39 and $50 \%$, included $X$. oryzae, X. bromi, $X$. vasicola $X$. cassavae and $X$. codiaei. The second group (2-27\% homology) included all other Xanthomonas strains. P. syringae pv. passiflorae showed $0.65 \%$ homology to the passiflorae strain. A homology of $67.5 \%$ was obtained with $X$. axonopodis. The standard deviation ranged from 0.01 to $6.8 \%$, excluding $X$. cassavae, which presented a considerable variation $(18.5 \%$ ), and $X$. melonis and X. oryzae (both $\sim 8.5 \%$ ). Pairwise comparisons of the binding values between $X$. axonopodis and other species reported by Vauterin et al. (1995) with the values obtained here revealed some similarities. The major discrepancies in the homology were related to the species $X$. campestris and $X$.

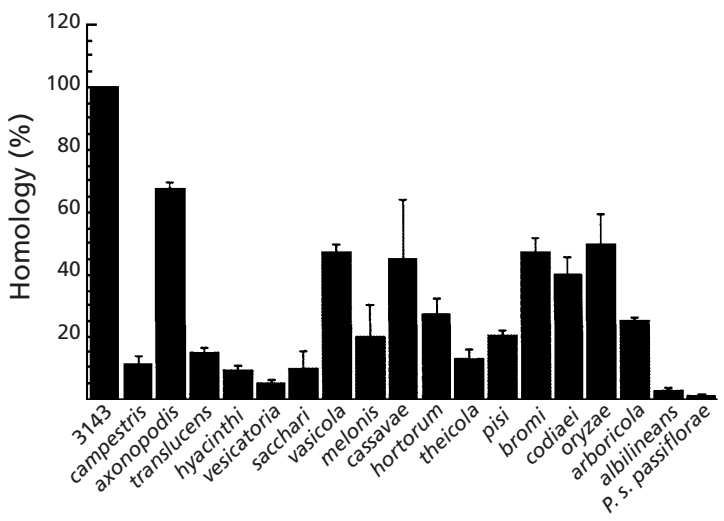

Fig. 7. DNA-DNA homology (\%) of the passiflorae ICMP 3151 (used as a probe) compared to different Xanthomonas species plus $P$. syringae pv. passiflorae.

vesicatoria, which had values lower than $15 \%$. In other cases, the relatedness between $X$. axonopodis and other Xanthomonas species was comparable, especially with the more distantly related species. Accordingly, the Xanthomonas species translucens, hyacinthi, sacchari, theicola and albilineans were the least related to $X$. axonopodis. The DNA-DNA hybridizations were repeated to confirm the homology of the passiflorae strain to $X$. axonopodis and its relationship to $X$. campestris. The results showed $54 \%$ homology of the passiflorae strain with $X$. axonopodis and $16 \%$ homology with $X$. campestris.

\section{DISCUSSION}

Few studies have been conducted with xanthomonads from passion fruit plants and here we present a first survey of strains in this group analysed by RAPD genomic fingerprinting. Extensive genetic diversity was observed and very few of the 55 strains of $X$. campestris pv. passiflorae studied were considered to be identical. The high level of polymorphism in these pathogens may be attributed to the long period of existence of Passiflora plants in Brazil. P. edulis is native in Southern Brazil and was introduced into other countries (Australia, South Africa, New Zealand, Hawaii and Kenya) in the nineteenth century for commercial purposes (see Smith, 1976). Similar diversity has been described for $X$. campestris $\mathrm{pv}$. manihotis in South America but is less in the more homogeneous populations of Africa where the Manihot plant was introduced more recently (Verdier et al., 1994). Three major clusters, which included most of the strains, and 12 minor clusters were observed in the passiflorae strains, based on a minimum level of similarity of $\sim 70 \%$. The pathogenicity of a representative strain of each cluster together with the pathovar reference strain (ICMP 3151) was confirmed by bacterial infiltration on detached leaves of $P$. alata. Two leaves per strain were inoculated with $20-50 \mu \mathrm{l}$ of 
a cell suspension with an $\mathrm{OD}_{600}$ of $0 \cdot 5$. All leaves showed a greasy halo $4-7 \mathrm{~d}$ after inoculation. No differences were detected in the severity of the symptoms. $X$. campestris $\mathrm{LMG} 568^{\mathrm{T}}$ was used as a control and only hypersensitive symptoms were visible after $30 \mathrm{~h}$ (data not shown). A correlation between the major clusters and the region of sampling was detected, with a specific cluster being predominant in each region. The genetic differences between the passiflorae strains collected in the Northern and Southern regions may indicate either that there is no transport of the plants (or seeds) between the two regions, or that the strains have a high ecological specificity. Indeed, the climate and rainfall conditions in both regions are quite distinct, which could explain the differences in the genomic structure of the populations. However, a more intensive sampling in the Northern region is required to confirm this correlation. Differences in the structure of a bacterial population incited either by geographical barriers (Adhikari et al., 1995; Restrepo \& Verdier, 1997) or by the hosts (Saux et al., 1998) have been described. Unfortunately, in the present work the hosts of the strains belonging to clusters XIII-XV were unavailable and the host-pathogen relationship could not be assessed.

Although the rep primers exploit more specific regions in the genome, the existence of a high level of polymorphism was confirmed by the amplification products obtained with these primers. A complex pattern of unique fingerprints was obtained for the 16 selected passiflorae strains and the 18 Xanthomonas species. The repetitive sequences ERIC and REP are highly conserved in eubacteria (Versalovic et al., 1991; Sharples \& Lloyd, 1990), including phytopathogenic bacteria such as Xanthomonas and Pseudomonas (Louws et al., 1994, 1995). In bacteria interacting with plants, these three sets of repetitive primers have revealed substantial polymorphism at an infraspecific level (Selenska-Pobell et al., 1995; Louws et al., 1994, 1995; Vinuesa et al., 1998). The evolutionary conservation of these repetitive elements in eubacteria has been explained by assuming they have a role in regulating important functions (Higgins et al., 1998). However, the extensive infra-specific level variation has not been explained. Indeed, each strain analysed yielded a strain-specific fingerprint, indicating a high level of changes generating distinct genomic structures. In Candida albicans (Scherer \& Stevens, 1998), repetitive elements may affect genomic stability by promoting chromosomal rearrangements or by providing hot-spots for recombination. In Escherichia coli, 500-100 copies of REP elements are present and because of the high level of homology among them (see Gilson et al., 1987) possibly they can act as homology cassettes. Such variation has also been reported for another repetitive element described by Leach et al. (1992).

The RFLP-IGS analysis, although performed with a limited number of restriction enzymes, was still able to detect diversity within the passiflorae group. In general, analysis of the 16S rDNA rather than the IGS has been employed more frequently in microbial systematics and phylogeny studies (Gutell et al., 1994). However Hauben et al. (1997) have shown that the extreme similarity in the 16S rDNA sequences of Xanthomonas species imposes limitations on attempts to establish a comprehensive view of the relationships among the different species.

In the present work, all 16 species of Xanthomonas were differentiated by the RFLP-IGS pattern, although the relationships among them did not reflect the relationships obtained by DNA-DNA hybridization (Vauterin et al., 1995) or 16S rDNA analysis (Hauben et al., 1997). However, the data were comparable when distant species were considered. Accordingly, the $X$. albilineans (comprising $X$. translucens, $X$. hyacinthi and $X$. theicola) and the $X$. sacchar $i$ cores are more distantly related to the other Xanthomonas species (the $X$. campestris core). Although only a few strains representing different Xanthomonas species were tested in the present work, the level of differentiation among them was striking. Indeed, the RFLP-IGS pattern using only three restriction enzymes, DdeI, HinfI and Sau3AI, was efficient in discriminating all 16 species of Xanthomonas. The passiflorae group could not be allocated to any Xanthomonas species based on the RFLP pattern and may therefore represent a new species. The species most related to the passiflorae strains were $X$. campestris and $X$. axonopodis, although the level of similarity was low $(\sim 59 \%)$. Indeed, the similarity between $X$. vasicola and X. cucurbitae, for example, was higher $(89 \%)$ than the similarity of the passiflorae group to any other Xanthomonas species $(<60 \%)$. Since it is not yet possible to establish the limits of RFLP-IGS in unambiguously delineating taxa at the species level, a greater number of strains representing each Xanthomonas species needs to be examined and the 16S-23S rDNA IGS sequences determined in order to establish the usefulness of this genomic region as a marker of genetic diversity and/or as a taxonomic tool. The heterogeneity in the 16S-23S rDNA IGS has been attributed to the number, length and composition of these spacers and it has been exploited to differentiate various bacterial species or strains (see Gürtler \& Stanisich, 1996). Although the 16S-23S rDNA IGS of Xanthomonas has not been analysed in detail, it is likely that a higher level of heterogeneity exists in this region than in the conserved 16S rDNA. A more detailed analysis of this region in Xanthomonas species may reveal the extent of the differences observed and also would allow the construction of a phylogenetic tree more consistent with the DNADNA hybridization data by defining more clearly the phylogenetic relationships of closely related species.

SDS-PAGE of whole-cell proteins revealed a very uniform pattern within the passiflorae group, as described for other pathovars of Xanthomonas (see Vauterin et al., 1991). In contrast, discriminating patterns were shown by different species of Xantho- 
monas. Since the passiflorae group was closely related to a major cluster comprising various Xanthomonas species, the taxonomic position of this group could not be assigned with certainty.

A general comparison of the approaches used in this study shows that they are not comparable since clustering obtained by one method was disrupted when another method was used. The results were therefore not sufficiently consistent to allow a taxonomic allocation of the passiflorae strains within the genus Xanthomonas. DNA-DNA hybridization, however, allocated this group to $X$. axonopodis with a mean homology of $60.7 \%$. This species is the largest and most genomically heterogeneous group in the Xanthomonas genus and includes 34 former $X$. campestris pathovars and $X$. axonopodis (Vauterin et al., 1995). Based on these results, a new designation of $X$. campestris pv. passiflorae as $X$. axonopodis pv. passiflorae is suggested. The pathovar characterization described by Pereira (1969) is maintained.

\section{ACKNOWLEDGEMENTS}

This work was supported by FAPESP (Proc. 90/7067-1). CNPq sponsored a studentship to E.R.G. The authors thank Dr L. O.S. Beriam and Dr J. Rodrigues Neto (IB/SBF) and Dr R. P. Leite (IAPAR) for providing the passiflorae strains, and Dr S. Hysiop for revising the English.

\section{REFERENCES}

Adhikari, T. B., Vera Cruz, C. M., Zhang, Q., Nelson, R. J., Skinner, D. Z., Mew, T. W. \& Leach, J. E. (1995). Genetic diversity of Xanthomonas oryzae pv. oryzae in Asia. Appl Environ Microbiol 61, 966-971.

Blum, H., Beier, H. \& Gross, J. J. (1987). Improved silver staining of plant protein, RNA and DNA in polyacrylamide gels. Electrophoresis 8, 93-98.

de Bruijn, F. J. (1992). Use of repetitive (repetitive extragenic palindromic and enterobacterial repetitive intergenic consensus) sequences and polymerase chain reaction to fingerprint the genomes of Rhizobium meliloti isolates and other soil bacteria. Appl Environ Microbiol 58, 2180-2187.

De Moreno, M. R., Smith, J. F. \& Smith, R. V. (1985). Silver staining of proteins in polyacrilamide gels: increased sensitivity through a combined Coomassie blue-silver stain procedure. Anal Biochem 151, 466-470.

Gilson, E., Rousset, J. P., Clement, J. M. \& Hofnung, M. (1987). Palindromic units: a case of highly repetitive DNA sequences in bacteria. Trends Genet 3, 226-230.

Gürtler, V. \& Stanisich, V. A. (1996). New approaches to typing and identification of bacteria using the $16 \mathrm{~S}-23 \mathrm{~S}$ rDNA spacer region. Microbiology 142, 3-16.

Gutell, R. R., Larsen, N. \& Woese, C. R. (1994). Lessons from an evolving rRNA: $16 \mathrm{~S}$ and $23 \mathrm{~S}$ structures from a comparative perspective. Microbiol Rev 58, 10-26.

Hauben, L., Vauterin, L., Swings, J. \& Moore, E. R. B. (1997). Comparison of $16 \mathrm{~S}$ ribosomal DNA sequences of all Xanthomonas species. Int J Syst Bacteriol 47, 328-335.

Higgins, C. F., McLaren, R. S. \& Newbury, S. F. (1998). Repetitive extragenic palindromic sequences, mRNA stability and gene expression: evolution by gene conversion? - a review. Gene 72, 3-14.

Honeycutt, R. J., Sobral, B. W. S. \& McClelland, M. (1995). tRNA intergenic spacers reveal polymorphisms diagnostic for Xanthomonas albilineans. Microbiology 141, 3229-3239.

Jackman, P. J. H. (1985). Bacterial taxonomy based on electrophoretic whole-cell protein patterns. In Chemical Methods in Bacterial Systematics, pp. 115-129. Edited by M. Goodfellow \& D. E. Minnikin. London: Academic Press.

Jahnke, D. D. (1994). A modified method of quantitative colorimetric DNA-DNA hybridization on membrane filters for bacterial identification. J Microbiol Methods 20, 273-288.

Leach, J. E., Rhoads, M. L., Vera Cruz, C. M., White, F. F., Mew, T. W. \& Leung, H. (1992). Assessment of genetic diversity and population structure of Xanthomonas oryzae pv. oryzae with a repetitive DNA element. Appl Environ Microbiol 58, 2188-2195.

Louws, F. J., Fulbright, D. W., Stephens, C. T. \& de Brujin, F. J. (1994). Specific genomic fingerprints of phytopathogenic Xanthomonas and Pseudomonas pathovars and strains generated with repetitive sequences and PCR. Appl Environ Microbiol 60, 2286-2295.

Louws, F. J., Fulbright, D. W., Stephens, C. T. \& de Brujin, F. J. (1995). Differentiation of genomic structure by rep-PCR fingerprinting to rapidly classify Xanthomonas campestris pv. vesicatoria. Phytopathology 85, 528-536.

Pereira, A. L. G. (1969). Uma nova doença bacteriana do maracujá (Passiflora edulis, Sims) causada por Xanthomonas passiflorae n.sp. Arq Inst Biol 36, 163-174.

Restrepo, S. \& Verdier, V. (1997). Geographical differentiation of the population of Xanthomonas axonopodis pv. manihotis in Colombia. Appl Environ Microbiol 63, 4427-4434.

Sambrook, J., Fritsch, E. F. \& Maniatis, T. (1989). Molecular Cloning : a Laboratory Manual, 2nd edn. Cold Spring Harbor, NY: Cold Spring Harbor Laboratory.

Saux, M. F.-L., Mauléon, H., Constant, P., Brunel, B. \& Boemare, N. (1998). PCR-ribotyping of Xenorhabdus and Photorhabdus isolates from the Caribbean region in relation to the taxonomy and geographic distribution of their nematode hosts. Appl Environ Microbiol 64, 4246-4254.

Scherer, S. \& Stevens, D. A. (1998). A Candida albicans dispersed, repeated gene family and its epidemiologic applications. Proc Natl Acad Sci USA 85, 1452-1456.

Selenska-Pobell, S., Gigova, L. \& Petrova, N. (1995). Strainspecific fingerprints of Rhizobium galegae generated by PCR with arbitrary and repetitive primers. J Appl Bacteriol 79, 425-431.

Sharples, G. P. \& Lloyd, R. G. (1990). A novel repeated DNA sequence located in the intergenic regions of bacterial chromosomes. Nucleic Acids Res 18, 6503-6508.

Smith, P. M. (1976). Minor crops. In Evolution of Crop Plants, pp. 301-304. Edited by N. W. Simmonds. New York: Longman.

Souza, J. S. I. \& Meletti, L. M. M. M. (1997). Maracujá: Espécies, Variedades, Cultivo, 1st edn. FEALQ, Piracicaba, Brazil: Fundação de Estudos Agrários Luiz de Queiroz.

Teixeira, C. G. (1994). Cultura. In Maracujá: Cultura, Matéria Prima, Processamento e Aspectos Econômicos, pp. 1-142 (Série Frutas Tropicais, 9). Campinas, Brazil: Instituto de Tecnologia de Alimentos.

Torres Filho., J. \& Ponte, J. J. (1994). Estudo sobre o controle da bacteriose ou "morte precoce" (Xanthomonas campestris pv. 
passiflorae) do maracujá amarelo (Passiflora edulis f. flavicarpa). Fitopatol Bras 18, 34-38.

Turner, T., Barber, C. \& Daniels, M. (1984). Behaviour of the transposons $\operatorname{Tn} 5$ and $\operatorname{Tn} 7$ in Xanthomonas campestris $p v$. campestris. Mol Gen Genet 195, 101-107.

Vauterin, L., Swings, J. \& Kersters, K. (1991). Grouping of Xanthomonas campestris pathovars by SDS-PAGE of proteins. J Gen Microbiol 137, 1677-1687.

Vauterin, L., Hoste, B., Kersters, K. \& Swings, J. (1995). Reclassification of Xanthomonas. Int J Syst Bacteriol 45, 472-489.

Verdier, V., Boher, B., Maraite, H. \& Geiger, J. P. (1994). Pathological and molecular characterization of Xanthomonas campestris strains causing diseases of cassava (Manihot esculenta). Appl Environ Microbiol 60, 4478-4486.

Versalovic, J., Koeuth, T. \& Lupski, J. R. (1991). Distribution of repetitive DNA sequences in eubacteria and application to fingerprinting of bacterial genomes. Nucleic Acids Res 19, 6823-6831.

Vinuesa, P., Rademaker, J. L. W., de Brujin, F. J. \& Werner, D. (1998). Genotypic characterization of Bradyrhizobium strains nodulating endemic woody legumes of the Canary Islands by PCR-restriction fragment length polymorphism analysis of genes encoding 16S rRNA (16S rDNA) and 16S-23S rDNA intergenic spacers, repetitive extragenic palindromic PCR genomic fingerprinting, and partial $16 \mathrm{~S}$ rDNA sequencing. Appl Environ Microbiol 64, 2096-2104.

Welsh, J. \& McClelland, M. (1990). Fingerprinting genomes using PCR with arbitrary primers. Nucleic Acids Res 18, 7213-7218.

Young, J. M., Saddler, G. S., Takikawa, Y., De Boer, S. H., Vauterin, L., Gardan, L., Gvozdyak, R. I. \& Stead, D. E. (1996). Names of plant pathogenic bacteria 1864-1995. Rev Plant Pathol 75, 721-763. 